\title{
Evaluation of cross breeding program involving Tsigai with Romney-Marsh and halfbred Lincoln-Tsigai breeds of sheep in dry steppe zone of Russia.
}

\author{
V. D. Milchevskiy ${ }^{1 *}$, A.M. Gadzhiev ${ }^{2}$, A.N. Doeva ${ }^{3}$, V. S. Gappoeva ${ }^{3}$, B. S. \\ Nikkolova ${ }^{3}$
}

\begin{abstract}
${ }^{1}$ All-Russian Research Institute of Animal Husbandry, Russia; ${ }^{2}$ Federal Scientific Agroengineering Center - All-Russian Institute of Mechanization, Moscow, Russian Federation; ${ }^{3}$ North-Ossetian State University named after K.L. Khetagurov, Vladikavkaz, 362025, Russian Federation.
\end{abstract}

*Corresponding author e-mail: xantarama@mail.ru

Journal of Livestock Science (ISSN online 2277-6214) 11: 133-138

Received on 22/3/20; Accepted on 20/8/2020

doi. 10.33259/JLivestSci.2020.133-138

\begin{abstract}
The experiment of crossing Tsigai ewes with Romney-Marsh and with the half-breed Tsigai-Lincoln rams in the southern dry steppes is described. 1873 Tsigai ewes were used in the experiment. They were artificially inseminated with 12 rams. Four Tsigai, four Romney-Marsh and four half-breed Lincoln-Tsigai rams were used for the experiment. 1930 lambs were born. By random sampling technique 300 purebred and 300 crossbred 2 months old lambs were selected for weighing. The Tsigai rams were heavier than the crossbred ones by $0.8 \mathrm{~kg}$ and the ewe-lambs - by $2.0 \mathrm{~kg}$, respectively. Then, individual records for 997 experimental ewe-lambs were carried out up to eighteen months. It was found that purebred progeny is more productive and viable than crossbred one. By the time of weaning, 4 months old purebred lambs were heavier than the crossbred ones by $1.7 \mathrm{~kg}$. At a year old, the Tsigai sheep were $0.7 \mathrm{~kg}$ heavier than the crossbred Tsigai-Romni-Marsh, and $2.67 \mathrm{~kg}$ heavier than the half breed Lincoln-Tsigai. According to the wool clip at one year of age, these differences were 0.17 and $0.19 \mathrm{~kg}$, respectively. The wool length of the crossbred ewe-lambs was 0.50 and $0.47 \mathrm{~cm}$ longer, but their wool in this indicator had greater variability, which is undesirable for homogenous wool. Crossbreds were also inferior according to the features expressed in points: class by 0.38 and 2.67 points, viability -0.38 and 0.56 points and consolidated estimate -1.79 and 3.26 points. When estimating all 12 rams for the complex of useful progeny features, two reliable improvers both Tsigai were found. Four reliable deteriorators were also identified, two of which were Romney-Marsh and two half breed Tsigai-Lincoln. All rams were kept in a special sheepherd in good conditions. Observing the Romney-Marsh (4 heads) and half breed Lincoln-Tsigai (4 heads) rams showed that they were constantly depressed, fell behind the Tsigai rams on the pasture, in moving and even at camps. The main conclusion of the experiment is that crossbreds are significantly inferior to Tsigai sheep in their viability, which is very important to know when breeding sheep in the harsh conditions of dry steppes and semi-deserts. The experiment gives ground to confirm that crossbreeding Tsigai sheep with Romney-Marsh and Lincoln cannot be achieved, at least, in the conditions of dry steppes. This zone doesn't require searching for countless combinations of breeds for crossbreeding because the analysis shows that experiment results are not as theoretically expected.
\end{abstract}

Keywords: crossbreeding of sheep; Tsigai; Romney-Marsh; breeds of sheep; selection and evaluation of breeds; natural zones 


\section{Introduction}

The research made by Z.V. Speshneva (Speshneva, 1950) found that for the South of Ukraine crossbreeding of Tsigai with long-wooled English meat breed (in this case, the same Romney-Marsh and probably Hampshire) is harmful, because the crossbreds productivity is lower than that of the parental breeds. According to the theoretical arguments of some authors (Severin, 1967) crossbreeding with Romney-Marsh breed when breeding Azov type in the same southern steppes of Ukraine (just east of Askania-Nova) was useful not to increase productivity but to loosen the conservative Tsigai sheep's heredity and thus create better opportunities for further breeding. Perhaps, this was true, theorist E.Ya. Borisenko indirectly agrees with this too (Borisenko, 1967). On the stud farm "Vlast Truda" according to the many years production data crossbred Romney-Marsh-Tsigai sheep of different generations were not inferior in productivity to purebred Romney-Marsh that for many generations were bred in the same environment and zone and, therefore, adapted. It remained unclear what breed was the improver - Tsigai or Romney-Marsh. Both breeds, in fact, were once brought to this zone and passed approximately the same periods of adaptation.

Crossbreeding is one of the widely used methods for rapid change of animals. There are about five thousand breeds of domesticated animals in the world, including more than a thousand breeds of domesticated sheep (Dankvert et al., 2010; https://reliefweb.int/report/world/second-report-state-worlds-animal-genetic-resources-food-and-agriculture, 2016). All these breeds to a certain extent is the material to create new more perfect, more modern selection achievements of what, actually, the essence of sheep breeding consists. The number of theoretically possible breed combinations for crossbreedings is inexhaustible. The simplest calculation shows that even fifty breeds can give 1225 combinations only of two breeds each. Combinations of three breeds will be about 20 thousand, four breeds - more than 230 thousand, etc. In general, all these combinations are theoretically more than all the sheep that exist in the world now and more than can appear in the coming centuries. To understand this diversity objectively, it is necessary to have very extensive scientific developments, as our colleagues do in related to the breeding serious studies on statistical analysis and modeling of technological processes in animal husbandry (Chabaev et al., 2018; Anikin et al., 2011).

In crossbreeding research is somewhat easier, but, of course, it is no accident that it is crossbreeding what a very significant part of introductions and research work in sheep breeding is dedicated to. So for the simple inquiry "sheep breeding" automated search system Library showed that only for 2018 from 243 found source names 49 sources that is, every fifth are in any case connected with crossbreeding of different breeds. These are mainly dissertations, reports on new types, heterosis from one new breed or another in commercial herds during meat production. Theoretically, such crossbreeding, especially the implemental, is justified simply and conventionally - by crossbreeds practicability to adapt to the conditions of housing, inherited from the "improved" local breed and high productivity of imported "improving" breed(www.activestudy.info/skreshhivanie-ego-biologicheskaya-sushhnost-i-znachenie-v-plemennom-i-polzovatelskomivotnovodstve, 2003).

It is obvious that to make a decision on any crossbreeding, the sheep breeder must clearly define the ultimate aim of sheep breeding, study the forecast of its achievement results and the methods of practical selection for the whole complex of interesting to the consumer useful features (Milchevsky, 2018). But where and how can he find out about it? Animal science literature on this issue, as a rule, reports successful variants of crossbreeding. For example, it has long been well known that in the world sheep breeding the crossbred trend is in the lead that also nowadays is confirmed by reports of sheep breeders from Australia and New Zealand (www.abc.net.au/news/rural, 2016).

This is a very convincing example of the successful application of crossbreeding with English early maturing breeds. There are other good variants. Failed variants of crossbreeding are usually not reported. It should be noted that in this very important matter for sheep breeding, many theoretical omissions are found and this is one of the problems in sheep crossbreeding. This article attempts to report our considerations and some research results on this issue. What can be useless or negative crossbreeding variants, when crossbreeding is necessary and when it is better to focus on purebred breeding, what's to be done to the fact that often variability of useful intrabreed features is higher, than interbreed ones, how to shift out unsuitable variants, not to wallow in unending combinatorics of breed names. The process of breeds creation most of all uses reproductive crossbreeding, due to which best qualities of these parental breeds must, however, be manifested and take root in crossbred progeny and, perhaps, new useful qualities but, of course, undesirable qualities must disappear, or come to nothing. Such in meaning definition of reproductive crossbreeding for all animal species is given in the textbook by E.Ya. Borisenko (Borisenko, 1967) and as such it is interpreted in a wide range people associated with animal husbandry. Similar in meaning definitions are given in textbooks in our field - sheep breeding (Erokhin et al., 2004; The Ministry of Agriculture of RF, order of October 5, 2010).

Breeders tested many thousands of interbreeding variants. The task was to obtain progeny, which can combine useful qualities of the parental breeds, manifest the effect of heterosis, or improve at least one of the selected features, without worsening the others. 


\section{Material and methods}

Such tasks were set in the described research on crossbreeding Tsigai sheep with English meat early maturing Romney-Marsh and Lincoln of different thorough-bredness in dry southern steppes. Purebred Tsigai ewes of the local pedigree herd, bred in the dry steppes were used in the study. They were mated with purebred Romney-Marsh and Lincoln-Tsigai rams of the first generation, grown in the middle Non-Chernozem fairly humid zone of Eastern Europe. The material for the analysis was the observational results for ewes, rams and their offspring and individual record of offspring productivity. This material was compared with the results obtained under the same conditions from similar Tsigai ewes when purebred breeding in the same flocks. This crossbreeding variant is not new for our sheep breeding. Similar crossbreeding of Tsigai sheep with English meat breeds was experimentally performed in Askania-Nova. Many years experiments were carried out under production conditions on the stud farm "Vlast Truda" in the forest-steppe zone, such crossbreeding was carried out when creating the Azov Tsigai type in the Azov region. There was no single common thought of this crossbreeding variant, interpretations of the results are contradictory (Milchevsky, 1998; Severin, 1967; www.abc.net.au/news/rural, 2016). The experiment was carrying on by the All-Russian Research Institute of Animal Husbandry in the areas near village Dubrovitsa, Moscow region.

The main conclusion of the experiment is that crossbreds are significantly inferior to Tsigai sheep in their viability, which is very important to know when breeding sheep in the harsh conditions of dry steppes and semi-deserts. The experiment gives ground to confirm that crossbreeding Tsigai sheep with Romney-Marsh and Lincoln cannot be achieved, at least, in the conditions of dry steppes.

\section{Result and Discussion}

For our experiment, three bands of ewes totaling 1873 heads were involved. They were artificially inseminated with 12 rams of different breeds and thorough-bredness. 1930 lambs were born. Then, detailed individual record of their productivity was performed. For all ewe-lambs individual records were performed up to eighteen months. Rams, most of which leave the herd before the weaning, could be weighed only the randomly selected 2-month-old lambs from the groups of purebred and crossbred of 300 heads each. It was found that Tsigai rams were significantly $(\mathrm{P}>0.99) 0.8 \mathrm{~kg}$ $(17.9-17.14 \mathrm{~kg}$ ) heavier than crossbred ones, and ewe-lambs, respectively, by $2 \mathrm{~kg}(17.2-15.2 \mathrm{~kg})$.

Further in the main experiment after thorough check of both parents origin 997 ewe-lambs - single-born were selected for the experimental groups. In addition, observing fathers of the experimental progeny - Romney-Marsh rams (4 heads) and half breed Tsigai-Lincoln rams (4 heads) were kept in a small (about a hundred heads) special sheepherd with complete feeding in a good house and on the best farm pastures together with Tsigai rams. Observation showed that these eight adult rams were constantly depressed, fell behind the Tsigai rams on the pasture, in moving and even at camps. On hot days, their breathing became so hurried that English rams could be unmistakably found among the adult herd by their often heaved sides. By the way, attentive sheep breeders can see the same picture at Russian sheep exhibitions held not in the hottest time of the year (end of May) in Elista, Ipatovo, Astrakhan, Rostov, etc. It is enough to go to the places for demonstration of semi-fine wool sheep and look at how breathe Tsigai sheep and sheep created on the basis of Romney Marsh, Lincoln, Texel and other advertised imported breeds. Similarly, in the described experiment, Romney-Marsh sheep and half breed Tsigai-Lincoln ones required increased attention, individual care, and even so were suitable for use as producers only two seasons at minimum load.

Wool of crossbreds obtained from these rams differed from wool of Tsigai counterparts, both in different and in the same areas of fleece - had no characteristic elasticity, was often cotted and felted, till the end of the wintering many animals suffered from the hairslip on their neck. Among the crossbreds there was great number of animals with the weak constitution, in species composition they were notably inferior to purebred counterparts. When measuring the productivity of experimental sheep, the results of visual expert observations were objectively confirmed. The expected heterosis was not detected. Crossbred ewe-lambs, who lived with Tsigai breed till valuation and clipping, somewhat exceeded them in wool length, differed little in the average fineness but were inferior in average body weight and wool clipping, that is, the most important useful features, for which they are bred.

Such features are also recognized in our experiment wool clipping, body weight, fineness and vitality. In the individual records the vitality is noted by reports on keeping the animal until weaning and up to valuation. In our analysis the fact that the animal lived to the valuation, the value of the viability indicator is 5 points, leave after weaning due to the sale for meat -4 points, keeping till weaning -3 points, leave before weaning due to the sale for meat -2 points, just birth -1 point. Quality class is divided into points as follows - elite -5 points, 1 st class -4 points, 2 nd class -3 points, without class -2 points, defect -1 point. Fineness is expressed by the degree of approximation to optimum, in our case to $30 \mu \mathrm{m}$ or 50 th quality. $30 \mu \mathrm{m}=5$ points, and for every two deviation units in one direction or another 1 point is taken off. So $28 \mu \mathrm{m}$ or $32 \mu \mathrm{m}=4$ points, $26 \mu \mathrm{m}=3$ points, etc.

A total of 8 features are included in the assessment. In addition, to get some idea of the overall benefit of all these indicators for all born animals, their consolidated estimate is also calculated. This is the sum of the ratio between each sheep indicator to its average value for all born, including those who left before the end of the experiment. The obtained data on the experimental ewe-lambs are shown in table 1. 
Table 1 Productivity of purebred and crossbred ewe-lambs

\begin{tabular}{|c|c|c|c|c|c|c|c|}
\hline \multirow{2}{*}{\multicolumn{2}{|c|}{ Feature }} & \multicolumn{2}{|c|}{$\begin{array}{l}\text { Tsigai, only } 462 \text { ewe-lambs } \\
\text { were born }\end{array}$} & \multicolumn{2}{|c|}{$\begin{array}{l}\text { Romney-Marsh - half } \\
\text { breed Tsigai, only } 440 \\
\text { ewe-lambs were born }\end{array}$} & \multicolumn{2}{|c|}{$\begin{array}{l}\text { Lincoln - Tsigai } 3 / 4 \text { blood for } \\
\text { Tsigai, only } 95 \text { ewe-lambs were } \\
\text { born }\end{array}$} \\
\hline & & $\begin{array}{l}\text { Ewe-lambs } \\
\text { with } \\
\text { recognized } \\
\text { indicator }\end{array}$ & Average & $\begin{array}{l}\text { Ewe-lambs } \\
\text { with } \\
\text { recognized } \\
\text { indicator }\end{array}$ & Average & $\begin{array}{l}\text { Ewe-lambs } \\
\text { with } \\
\text { recognized } \\
\text { indicator }\end{array}$ & Average \\
\hline \multicolumn{2}{|c|}{ Body wt at weaning, $\mathrm{kg}$} & 370 & $26.4 \pm 0.18$ & 300 & $24.7 \pm 0.21$ & 61 & $24.7 \pm 0.45$ \\
\hline \multicolumn{2}{|c|}{ Wool length at weaning, $\mathrm{cm}$} & 370 & $4.5 \pm 0.06$ & 300 & $5.0 \pm 0.08$ & 61 & $4.97 \pm 0.11$ \\
\hline \multicolumn{2}{|c|}{ Wool length at 1 year of age, $\mathrm{cm}$} & 300 & $10.8 \pm 0.08$ & 228 & $10.9 \pm 0.13$ & 39 & $10.6 \pm 0.23$ \\
\hline \multirow[t]{2}{*}{ Fineness } & in points & 300 & $4.08 \pm 0.017$ & 228 & $4.07 \pm 0.034$ & 45 & $3.90 \pm 0.126$ \\
\hline & $\mu \mathrm{m}$ & 300 & $28.5 \pm 0.05$ & 228 & $28.5 \pm 0.07$ & 45 & $29.3 \pm 0.38$ \\
\hline \multicolumn{2}{|c|}{ Body wt at 1 year of age, $\mathrm{kg}$} & 300 & $34.5 \pm 0.21$ & 228 & $33.8 \pm 0.25$ & 45 & $31.93 \pm 0.621$ \\
\hline \multicolumn{2}{|c|}{ Wool clipping at 1 yer age, $\mathrm{kg}$} & 300 & $3.63 \pm 0.03$ & 228 & $3.46 \pm 0.04$ & 45 & $3.44 \pm 0.13$ \\
\hline \multicolumn{2}{|c|}{ Class at 1 year of age, point } & 300 & $4.31 \pm 0.249$ & 228 & $3.45 \pm 0.05$ & 45 & $1.64 \pm 0.13$ \\
\hline \multicolumn{2}{|c|}{ Viability, point } & 462 & $3.94 \pm 0.07$ & 440 & $3.56 \pm 0.09$ & 95 & $3.38 \pm 0.19$ \\
\hline \multicolumn{2}{|c|}{$\begin{array}{l}\text { Consolidated estimate of animal's } \\
\text { benefit according to all } 8 \text { features, } \\
\text { points }\end{array}$} & 462 & $9.1 \pm 0.25$ & & $7.31 \pm 0.27$ & & $5.84 \pm 045$ \\
\hline
\end{tabular}

Table 2. The results of evaluating rams by progeny according to the complex of 8 features

\begin{tabular}{|l|l|l|l|l|l|l|l|l|}
\hline $\begin{array}{l}\text { Sire } \\
n\end{array}$ & Class & $\begin{array}{l}\text { Absolute } \\
\text { difference }\end{array}$ & $\begin{array}{l}\text { Probability } \\
\text { level }\end{array}$ & $\begin{array}{l}\text { Progeny } \\
\mathrm{n}\end{array}$ & $\begin{array}{l}\text { Number of } \\
\text { counterparts }\end{array}$ & $\begin{array}{l}\text { Progeny } \\
\text { average }\end{array}$ & $\begin{array}{l}\text { Counterparts } \\
\text { average }\end{array}$ & $\begin{array}{l}\text { Breed and thorough- } \\
\text { bredness of ram-father }\end{array}$ \\
\hline 64 & 9 & -1.52 & 0.9 & 42 & 955 & 6.55 & 8.06 & Tsigai - half breed Lincoln \\
\hline 8020 & 10 & -1.67 & 0.6 & 11 & 986 & 6.35 & 8.02 & Tsigai - half breed Lincoln \\
\hline 70017 & 5 & -0.35 & 0.4 & 85 & 912 & 7.68 & 8.03 & purebred Romney-Marsh \\
\hline 70625 & 6 & -0.72 & 0.7 & 98 & 899 & 7.35 & 8.07 & purebred Romney-Marsh \\
\hline 70662 & 8 & -1.00 & 0.95 & 151 & 846 & 7.15 & 8.15 & purebred Romney-Marsh \\
\hline 70664 & 7 & -0.87 & 0.8 & 106 & 891 & 7.22 & 8.09 & purebred Rombey-Marsh \\
\hline 71887 & 2 & 1.25 & 0.98 & 147 & 850 & 9.07 & 7.82 & purebred Tsigai \\
\hline 72159 & 1 & 1.94 & 0.999 & 120 & 877 & 9.71 & 7.77 & purebred Tsigai \\
\hline 73077 & 3 & 0.92 & 0.8 & 103 & 894 & 8.83 & 7.91 & purebred Tsigai \\
\hline 73346 & 4 & 0.71 & 0.7 & 92 & 905 & 8.64 & 7.93 & purebred Tsigai \\
\hline 80227 & 12 & -3.81 & 0.99 & 21 & 976 & 4.27 & 8.08 & Tsigai - half breed Lincoln \\
\hline 80426 & 11 & -2.31 & 0.9 & 21 & 976 & 5.74 & 8.05 & Tsigai - half breed Lincoln \\
\hline
\end{tabular}

It should be noted that these indicators are recorded at the stage of natural selection, when its action is basically over, that is, the non-viable animals have not lived up to this point. The viability of the crossbred ewe-lambs as seen in the table, was significantly lower compared to the purebred Tsigai breeds. It is also important that among crossbred sheep there were no animals outstanding at least for one feature, that is, the effect of heterosis was not manifested both in general and in individual cases.

For the same 997 ewe-lambs all their 12 fathers of progeny were evaluated for all eight and recognized features and derived from all eight features the consolidated complex estimate, which shows the results obtained (table 2).

The table shows that two of the twelve rams were the progeny improvers with the probability level $(\mathrm{P}>0.9)$. Four rams with the same probability level were complex progeny deteriorators. Both improvers belonged to Tsigai breed, all four deteriorators to the purebred Romney-Marsh and Tsigai-Lincoln ones.

The experiment gives grounds to confirm that the aim for which it would be worth crossbreeding Tsigai sheep with Romney-Marsh and Lincoln cannot be achieved, at least in the conditions of dry steppes, the resulting crossbreds in the first generation obviously degenerate, their productivity does not exceed the productivity of the parental breed, and by a number of indicators is reduced. The thesis of Z.V. Speshneva (Speshneva, 1950) about the futility of described here crossbreeding variants for the South Ukrainian steppes is also confirmed for hundreds of kilometers east of them, in fact, for the entire dry-steppe zone. As we see, not only those features are inherited, for which the known breed was recognized in the homeland, but mostly its the negative features. At the same time, the lack of strictly experimental data on the potential of local adapted for centuries breeds and the contradiction of the actual data on the productivity of 
imported breeds in new for these breeds conditions according to available sources of information (including, unfortunately, manuals and official recommendations) often gives rise to spontaneous unwise crossbreeding (Standards for the complex assessment of breeding and productive qualities of semi-fine-wool sheep with bases of breeding work, 2008; Erokhin et al., 2004).

The desire to solve all problems by crossbreeding, gradually, begins to yield to a more sober approach to this, though powerful, but by far not universal method of breeding. On the international level breeding specialists recognize the threat for animals' genetic diversity due to disorderly crossbreeding with the imported breeds and ignoring local breeds (https://reliefweb.int/report/world/second-report-state-worlds-animal-genetic-resources-food-and-agriculture, 2016). In Mongolia, where sheep breeding is at the same dry territories, scientists have already ensured of developing the systems for animal husbandry, including "integrated approach combining improved management of animals and the marketing of breeding activity but not a single promotion practices such as crossbreeding with indigenous breeds (Andreas, 2017).

In sheep breeding in the above-mentioned territories, mainly in the CIS, the daily painstaking work on breeding, selection and finding of parents-progeny improvers is replaced by this, not always justified, method and natural subsequent failures and disappointments not so much by the performers as by their successors. There are many examples of this (Filatova, 2016). Especially disastrous were the consequences of crossbreeding fat-tailed fine-wool and semi-finewool sheep in almost all sheep-breeding zones of Russia. If to pass the whole zone of the main concentration of finewool sheep breeding of Russia in steppes and semi - deserts of Stavropol and Kalmykia to the Caspian sea - so it is possible to observe with regret that here exactly the number of sheep flocks became many times less, and those that come into the view are not fine-wool, and generally pied, but also not fat-tailed, simply not selected crossbreds reminding primitive low-productive herds of North Africa and the Middle East which maintenance is performed by the primitive way, of course, without any selection techniques. Meanwhile, with the filing of experts who believe in easily accessible wonders of crossbreeding, many new incompetent herds owners and with the connivance of regulatory authorities, sheep with homogenous wool are replaced by crossbred pied, as a rule, with the same meat productivity, but without quality wool, and most important - with a shaken heredity and the prospect of spending many years to return their useful qualities at least to the previous level. To a large extent, this is supported by the so-called theoretical regulations that it is necessary to create good feeding and housing conditions for crossbred livestock (Borisenko, 1967). This regulation does not withstand basic logical analysis, contributes to the show and record mania.

The trend of ruminant production in the world has been towards specialization and intensification, and producers have emphasized production at the expense of profit without linking ecologically the animals to the landscapes they inhabit. In this context, public policies usually support producers in the use of a reduced number of specialized breeds in order to reach the market needs and obtain higher economic returns (de la Barra et al 2012). Most programs have either resorted to cross-breeding with exotic breeds or importing live animals but particular attention should be given to animal breeds with adaptation to the local environment (Martines et al 2012).

How often we see gorgeous animals on exhibitions, which are presented as results of crossbreeding with a new fashionable breed and here, is new selection achievement. But in fact it is just an animal selected by phenotype from a large number of counterparts and well-fed in a separate exhibition group. Such animals exist in any breed and they can be found and grown for demonstrations virtually in any herd. For the thinking breeder it is quite clear that it is necessary to create good conditions for all animals of all breeds, all blood, all productivity directions. And results that do not mislead experts about the animals' merits can be obtained only in equal conditions. And it relates directly to researches on sheep selection.

The main conclusion of the experiment is that crossbreds are significantly inferior to Tsigai sheep in their viability, which is very important to know when breeding sheep in the harsh conditions of dry steppes and semi-deserts. The experiment gives ground to confirm that crossbreeding Tsigai sheep with Romney-Marsh and Lincoln cannot be achieved, at least, in the conditions of dry steppes.

\section{References}

1) Andreas W. Wilkes et al. 2017. Is cross-breeding with indigenous sheep breeds an option for climate-smart agriculture? Andreas Wilkes and others.- 147: 83-88

2) Anikin A.S., Nekrasov R.V., Golovin A.V., Pervov N. G., Chabaev M. G. 2011. Principles of energy rationing for highly productive lactating cows. Animal science. 10: 11-12.

3) Borisenko E.Ya. Farm animals breeding. Kolos Press.- Moscow 1967 - 406 p.

4) Chabaev M.G.,Yuldashbaev YU.A., Baeva Z.T., Gappoeva V.S., Galicheva M.S. 2018. Blood morphology and biochemistry of dairy cattle when chelate preparation is introduced into diets . Pollution Research. 37(4): 898-90

5) Crossbreeding, its biological essence and value in pedigree and user animal husbandry. Source: http://www.activestudy.info/skreshhivanie-ego-biologicheskaya-sushhnost-i-znachenie-v-plemennom-ipolzovatelskom-hivotnovodstve/ .- Faculty of animal science, Moscow Timiryazev Agricultural Academy.2003. 
6) Dankvert S.A., Kholmanov A.M., Osadchaya O.Yu 2010. World sheep breeding. - reference and training manual.Moscow. Ministry Of Agriculture RF.- RAAS. - All-Russian Research Institute for Animal Husbandry.- pp. 35.

7) de la Barra R., Martínez M.E. and Carvajal A.M. 2012. Genetic relationships between Chilota and Spanish native sheep breeds of Chile. Journal of Livestock Science (ISSN online 2277-6214) 3: 79-84,

8) Erokhin A.I. Erokhin S.A. 2004. Sheep Breeding- textbook for Universities- Ministry of Agriculture RF.Moscow Timiryazev Agricultural Academy. Pp. 116

9) Filatova A.L. 2014. Prospects of Tigai sheep breeding in the South of Russia.- Sheep, goats, wool industry. 3: 4-6

10) Martínez M.E., Calderón C., Uribe H., de la Barra R. 2012. Effect of management practices in the productive performance of three sheep breeds in the Chiloé Archipelago, Chile. Journal of Livestock Science 3: 57-66,

11) Milchevsky V.D. 2018. Determination of the ultimate aim of sheep breeding, the forecast of its achievement results by selection and practical selection techniques for a set of features.- AEconomics: Economics and agriculture. 2 (26): 8-13.

12) Milchevsky V.D. 1998. Some thoughts on crossbreeding in Tsigai sheep breeding.- Journal "Sheep, goats, wool industry."- Vol 1.

13) One of Australia's oldest cross bred sheep featured at Sydney Royal https://www.abc.net.au/news/rural/2016...breed.../7279588.

14) Order and conditions of valuating pedigree sheep of fine-wool, semi-fine-wool and meat breeds. (App. The Ministry of Agriculture of RF, order of October 5, 2010 №335, registered in Ministry of Justice RF on November 22, 2010 №19006).- 7, 20 p.

15) Severin V.S. 1967. Priazovsky type is the pride of the stud farm staff. - Journal "Sheep breeding". Vol. 7

16) Speshneva Z.V.1950. Comparison in efficiency of crossbreeding Tsigai sheep with the English meat breeds: Hampshire and Romney-Marsh.- author's abstract. - "Askania-Nova".6: 710 p.

17) Standards for the complex assessment of breeding and productive qualities of semi-fine-wool sheep with bases of breeding work.- Ministry of Agriculture RF.- Department for animal husbandry and breeding affairs of the Ministry of Agriculture .- 2008. - 7-11, 37 p.

18) The Second Report on the State of the World's Animal Genetic Resources for Food and Agriculture.https://reliefweb.int/report/world/second-report-state-worlds-animal-genetic-resources-food-and-agriculture.Published on 27 Jan 2016. 